\title{
Development of Creative Product And Entrepreneurship Textbook With Strengthening the Production-Based Mindset In Vocational School of Tourism
}

\author{
$1^{\text {st }}$ Rotua Sahat Pardamean Simanullang ${ }^{1}, 2^{\text {nd }}$ Sri Mutmainnah $^{2}, 3^{\text {rd }}$ Ellys Siregar $^{3}$ \\ \{rotua@unimed.ac.id ${ }^{1}$ \} \\ Universitas Negeri Medan, Medan, North Sumatera ${ }^{1,2,3}$
}

\begin{abstract}
This research aims to produce a Creative Product Textbook and Entrepreneurship for Vocational School of Tourism, which was developed by strengthening the production-based mindset. With the development of this textbook will improve: (1) interest in becoming an entrepreneur in the tourism business based on the planting of values and providing positive information on the role and presence of entrepreneurs in nation building, (2) the ability of students to produce products that are needed by the market in the tourism business by utilizing all the potential of nature, humans and culture around them (3) the ability of students to market the products produced to the public, both tourists and potential tourists. This research uses a development research approach Borg and Gall, with data collection techniques using questionnaires and interview guidelines. The research began in the first stage of researching and preliminary studies by seeking information regarding the existence of the PKK book. The second stage, FGD with teachers of Vocational School of Tourism for initial data collection by analyzing the need for PKK textbooks, determining learning experiences and general goals. The third stage, developing textbooks by adding material for strengthening mindsets by building students' mindsets to dare to try, dare to go out of their comfort zone and dare to fail as a motivation. The fourth stage, conducting initial trials with validation from tourism material expert, marketing expert and book design expert. After that, it was continued with an one by one trial with 3 students to see the depth of content, readability and ease of understanding. Fifth stage, after receiving input from expert and students, improvements are made to the textbook products that are being developed. From input of expert and one by one trials, it was concluded that the PKK textbooks developed were: 1) interesting; 2) easy to understand; and 3) build students' mindsets to dare to be entrepreneurs.
\end{abstract}

Keywords: Mindset, research development, and production-based learning .

\section{Introduction}

The government is currently focusing its policies on developing creative and reliable human resources who will act as agent of economic development as productive citizens who create jobs for themselves and for others. The government designs various businesses how to create young entrepreneurs to be able to utilize of local potential and the development of 
information technology into economic resources [1]. This government effort is carried out by realizing that being an entrepreneur is not easy and instant, but is a behavior that must be cultivated from an early age [2].

One of the government's focuses in developing entrepreneurship is among Vocational High Schools (SMK). Minister of Education and Culture Regulation No. 34 of 2018 formulates the specific goals of Vocational Schools to be able to produce skilled workers who have the abilities according to the demands of the business/industry world, and are able to develop their potential in adopting and adapting to the development of science, technology and art. To support the profile of Vocational Schools as entrepreneurs, the subject of Creative Products and Entrepreneurship (PKK) is part of the curriculum as a compulsory subject with 7 to 8 hours of lessons per week. This is done to cultivate interest, enthusiasm and entrepreneurial skills that will generate to entrepreneurs, as an effort to reduce unemployment for vocational school graduates which is still quite high. Data from BPS for the last 5 years there has been an increase in the open unemployment rate (TPT) for SMK/MAK graduates from $20.41 \%$ in 2016 showing an increase every year to reach $22.58 \%$ in 2020.

Vocational School of Tourism is one of the majors mandated for the creation of young entrepreneurs who will act as agents of economic development. Vocational School of Tourism is a major that is in great demand, as can be seen from the addition of the opening of the tourism department and the increase in the number of students accepted each year. This is also motivated by the large market opportunity in the tourism industry which requires quite a lot of middle manpower. Tourism is becoming a big business, millions of people want to utilize of their free time by traveling, medical and religious trips. Data from the World Travel \& Tourism Council (WWTC), prior to the Covid-19 pandemic that tourism was an important contributor to the Indonesian economy, contributed more than 55 percent of service sector exports. In line with data from the Central Statistics Agency (BPS) for the last 5 years there has been an increase in the percentage of the number of workers in the tourism sector to total workers, starting with $9.03 \%$ in $2015 ; 10.37 \%$ in $2016 ; 10.53 \%$ in $2017 ; 11.17 \%$ in 2018 to $11.83 \%$ in 2019 . The tourism sector is also able to generate 2.4 million new jobs and contribute 6.2 percent to Indonesia's gross domestic product.

The development of entrepreneurial interest in students of vocational school must start from planting a positive mindset related to the status of entrepreneurs and must be carried out in a planned and strategic manner to prepare a productive and character generation. The entrepreneurial mental attitude among students of vocational school must be developed systematically in line with the development of existing business opportunities in the community which will be useful as human resource capital in development. The cultivation of an entrepreneurial mental attitude can be through structured education and training to be able to utilize of the existing potential into economic opportunities [3]. Entrepreneurship is the integration of the dimensions of attitude, knowledge and skills that still considers the stages of psychological development of students, especially the dimensions of attitude, internalization of values through exemplary strategies; giving advice according to the context of the material, time and place; positive and negative reinforcement; habituation and conditioning. That is why in entrepreneurial learning the process of internalizing values to students needs to be carried out, because the learning should not only be theory, but practice to become an entrepreneur [3];[1]. The development of entrepreneurial interest for students of Tourism Vocational High School is seen as strategic to prepare a productive generation and have the character of creative entrepreneurs who are able to utilize of developments in information technology, social media, tourism industry development and stakeholder needs. 
The development of the tourism industry can increase job opportunities for many people, including for graduates of Tourism Vocational School who choose to become entrepreneurs, as stated by Gunawan and Adikampa [4] in their research that the development of tourism has increased job opportunities in the community both directly and indirectly. Direct job opportunities are felt directly by people working in the tourism sector, while indirect job opportunities will be felt by people who work in sectors related to tourism activities such as suppliers of all tourist needs. For this reason, the preparation of vocational school graduates as productive middle workers who are ready to work and enter the world of work is largely determined by the learning activities that occur in schools as a place for them to explore their abilities during the teaching and learning process at school which will be an experience that will be embedded in students.

The implementation of the 2013 Curriculum in schools currently provides opportunities for students to explore skills more comprehensively for mastery of theory, practice and alignment with attitudes in student life. Students are given the opportunity to explore their potential by doing $5 \mathrm{M}$ activities, namely observing, exploring deeper by asking questions and collecting information related to the ongoing learning theme. Then enter the associating and analyzing phase which usually relates to conditions in reality to be able to make decisions on the themes discussed and then communicate their findings. Students can explore, assess, interpret, synthesize, and provide information to produce various forms of learning outcomes. Lestari [5] said that learning with the 2013 Curriculum in the Education unit must be held interactively, inspiring, fun, challenging, motivating students to actively participate, and providing sufficient space for initiative, creativity, and independence according to talents, interests and physical development as well as student psychology. The focus of the development of the 2013 Curriculum lies in the attitudes, knowledge and skills of students in deep learning experiences that have an instructional and natural influence. Haryati Nisa, et al [6] suggest that the choice of collaborative learning in the 2013 Curriculum learning is an option where interaction between students in certain contexts through communication between participants to exchange opinions and work together actively in groups. More specifically, Ayu Sulastri [3] stated that collaborative learning with models of production-based learning is highly expected in the implementation of the 2013 Curriculum. Nuri and Ani Rusilowati [7] said that production-based learning for SMK students is an effort to equip entrepreneurship skills and enter the world of work, which in the learning process students are active and collaborative in groups to produce a joint product that is ready to be entered into the industrial world in the community. Giving assignments to produce products in groups will familiarize students with practicing to design products, carry out the production process, evaluate the products produced, and plan their marketing, to evaluate the products produced. Mitasari and Rusdarti [8] suggest that the production-based learning model is an education and training process that is integrated into the production process, where students are given learning experiences in contextual situations following the flow of industrial work starting from planning based on orders and the main target of this learning model is so that graduates can play a role in increasing the empowerment of regional potential to spur economic growth.

For this reason, the entrepreneurial competence of Tourism Vocational School students needs to be improved, with the support of textbooks that can strengthen positive mindsets by providing positive and constructive information, motivational sentences, displaying tourism market potential, showing profiles of successful tourism entrepreneurs, showing local potential that is ready to become a tourist attraction. This information is expected to be a mindset that will influence students' behavior and way of thinking. Textbooks with an emphasis on cultivating values by strengthening students' mindsets will increase students' 
interest in becoming entrepreneurs in the tourism business. The production-based approach will familiarize students with learning experiences in contextual situations that follow the flow of work in the tourism industry, from business planning, implementation, product evaluation to post-product services. For this reason, it is necessary to develop textbooks of Creative Products and Entrepreneurship by strengthening the production-based mindset to improve the entrepreneurial competence of Tourism Vocational School students so that students are motivated and practice producing products that are in accordance with market demands.

This research is expected to contribute to the improvement of the quality of Creative Products and Entrepreneurship learning that takes place at the Tourism Vocational School, which will have an effect on increasing students' interest and understanding of tourism business entrepreneurship. This increase in interest is expected to motivate students and graduates to become entrepreneurs who are able to utilize of regional potential into business opportunities and become job providers. Which broadly and in the long term will affect the development of society as an agent of economic change that determines the progress of the nation in the future.

\section{Methods}

This research uses the Research and Development method ( $R$ \& D) to produce products in the form of Creative Product and Entrepreneurship Textbooks with Production-based Mindset Strengthening with the Borg and Gall R \& D Model consisting of ten implementation steps including (1) research and information collecting, (2) planning, (3) develop preliminary form of product, (4) preliminary field testing, (5) main product revision, (6) main field testing, (7) operational product revision, (8) operational field testing, (9) final product revision, and (10) disemination and implementation.

The location of this research took place in the Travel Department of SMK Negeri 7 Medan. The population in this research were students of SMK 7 Department of Travel Business who followed Creative Products and Entrepreneurship Subjects. The R\&D research sample has trial stages starting from the one by one trial stage, small group trial and large group trial. So the sample is all respondents involved at each stage of the trial. The research subjects in this study were one material expert, one learning design expert, one linguist expert and Tourism Vocational School students.

Data collection techniques used in this study were questionnaires and interviews, with the instruments used were questionnaire questions and interview guidelines. Questionnaires and interview guidelines were used to collect review data from content expert, instructional design expert, linguist expert, and students during individual, small group and field trials. Analytical techniques with qualitative descriptive analysis techniques were used to process the data from the review results from content expert, learning design expert, linguist expert and students during individual, small group and field trials. This data analysis technique is carried out by grouping informations from qualitative data in the form of input, feedback, criticism, and suggestions for improvement contained in the questionnaire and interview results. The results of this data analysis are then used to revise the product for the Creative Products and Entrepreneurship Textbook for Tourism Vocational Schools. Quantitative descriptive statistical analysis will be used to analyze quantitative data on the responses to assessments made by students during individual, small group and field trials. 


\section{Result and Discussion}

The development of Creative Products and Entrepreneurship textbooks for Tourism Vocational School students follows the Borg and Gall development procedure with ten steps of development, but this research will stop at the fifth stage.

\subsection{Headings, tables and figures}

At this stage, a preliminary study was conducted in the form of observing the availability of Creative Products and Entrepreneurship textbooks in the community and schools. Activities carried out by studying the material content of existing books and used in schools. The results found. Preliminary studies that have been carried out have many books on Creative Products and Entrepreneurship that have been traded, but most of the books are still general in nature for all majors with an emphasis on theory related to the syllabus. There are also several books that already specialize in the study of their majors, such as Books on Creative Products and Entrepreneurship for Automated Vocational Schools. The existing textbooks also focus on the theory of entrepreneurship but not on the practical aspects. It is difficult to find an entrepreneurship book that focuses on the practice of producing products in the tourism business by marketing them.

The available textbooks are also still more focused on entrepreneurship theory, no one has looked at the cultivation and strengthening of students' mindsets to want to become entrepreneurs. Becoming an entrepreneur does not start from understanding theory but from changing the mindset because to be an entrepreneur, students should be able to sort and choose information, look for role models and sources of inspiration as idols who become role models for every student to adopt their way of thinking or mindset. For this reason, it is necessary to cultivate a positive mindset in every learning activity so that this can be embedded in the minds of students and form a positive mindset in them to be able to grow and rise to become young entrepreneurs.

Information collection was also carried out through interviews with the Head of the Tourism Department of SMK Negeri 7 who stated that the textbooks used in this school were general Creative Products and Entrepreneurship books whose studies were more on the entrepreneurial aspect in general, not specifically related to entrepreneurship in the tourism sector. Learning activities for Creative Products and Entrepreneurship are already participatory learning based on project learning. Students are asked to design and produce a product and it will be displayed and sold at school fairs. Students have not been oriented to produce products according to the needs of industry and society. The products produced are still on the needs of students who will be purchased by fellow students, parents of students who attend the bazaar and school teachers. Students have not designed industrial products according to the needs of prospective consumers in the form of travel designs, attractions, souvenirs, culinary and clothing to be designed to enter the market either through networks or outside the network, students have not planned the marketing of the service products they produce in a more planned manner through the media proper marketing.

\subsection{Planning for Creative Products and Entrepreneurship Textbooks}

After conducting a preliminary study and obtaining information as a first step to identify and explore the need for textbooks, then the product planning for the creation of Creative and 
Entrepreneurial Products textbooks for Tourism Vocational Schools students, including by determining learning objectives based on the Spectrum of Expertise of the Vocational High School, Department of Tourism. in the Regulation of the Director General of Primary and Secondary Education of the Ministry of Education and Culture Number 06/D.D5/KK/2018 and the Syllabus of Creative Products and Entrepreneurship Subjects.

For this planning activity, the participation of Tourism Vocational School teachers was also involved by conducting a Group Discussion Forum with the Head of the Tourism Department and Teachers of Creative Products and Entrepreneurship subjects at SMK Negeri 7 Medan. FGD were carried out to further focus on planning the format of the textbooks to be developed, detailing the profiles of SMK Tourism graduates, focusing on PKK learning objectives to support the achievement of graduate profiles, discussing the material framework and the sequence of teaching and collecting materials.

Based on the characteristics of the material of Creative Products and Entrepreneurship which are full of practice, a production-based textbook is needed with the strengthening of entrepreneurial mindsets in students. Creative Products and Entrepreneurship textbooks that will be developed by strengthening the production-based mindset of students with the suitability of the material in the 2013 Curriculum syllabus.

\subsection{Product Draft Development}

Production-based Creative Products and Entrepreneurship textbooks are developed based on learning design theory, which includes material that aims to facilitate the student learning process. Textbooks developed based on production-based learning have the characteristics of solving problems in the real world. Textbooks will always begin with positive reinforcement as an effort to cultivate a positive mindset to become an entrepreneur, in the form of strengthening sentences, biographies of successful business actors in the tourism sector, pictures of tourism potential that are ready to be developed, links to learning videos and videos that can be accessed, and so on. as a giver of positive encouragement interested in becoming entrepreneurs in the tourism business. In addition, textbooks will have core components in production-based learning including: 1) communicative content descriptions, 2) using examples, illustrations or analogies, 3) using exercises, tests, and corrective feedback, 4) selecting relevant media, 5 ) relevance and consistency between exercises or tests and learning objectives material and 6) interactivity [9].

The required textbooks must begin with building the mindset of being an entrepreneur, developing balanced theoretical and practical skills where students must be trained to design tourism products such as travel services that are ready to be launched to the public, culinary standards according to health, cleanliness and appearance, souvenirs that are ethnic and full of meaning, interesting local game shows and other attractions. So that students have conceptual skills and the courage to enter the industry as actors. For this reason, there is a need for standardization: learning indicators, content of teaching materials, learning models, evaluation instruments as outlined in the Production-based Creative Products and Entrepreneurship Textbook so that every Tourism Vocational School student has competence in accordance with the needs of the industrial world.

Product development is carried out in stages, starting with early stage development. After the textbook framework is formed, the development of the book content section begins because it is the most important thing related to the learning content that will be carried out. The book content section for each chapter always begins with providing motivation and efforts 
to develop students' mindsets in the form of motivational sentences, pictures and video links that contain tourism potential that can be owned and developed, as well as the existing market potential. Then proceed with technical instructions for use, introduction to the material, core material, conclusions and exercises. For practice and evaluation, it always focuses on familiarizing students with producing products that are adapted to existing material. Thus, students' habituation efforts to analyze and take action decisions will be trained. So students are always directed to learn high order thinking skill (HOTS).

After the new contents go to the initial cover design section and the back cover of the textbook. The initial cover consists of pictures, book titles, authors, preface, SK, KD and table of contents. While the final cover contains a glossary, a list of references and a final skin.

\subsection{Preliminary Field Testing}

This initial field test relates to product assessment and validation carried out by experts, which aims to determine the improvement in the development of the PKK Textbook that is carried out as well as assessing the feasibility of the product developed based on comments and suggestions given by experts using a questionnaire given to tourism material expert, marketing expert and book design expert.

The results of the validation of tourism materials expert concluded that the material in the production-based PKK textbook for strengthening the entrepreneurial mindset of students was very good, because it was in accordance with the spectrum and the existing syllabus was enriched with an introduction to motivate students to become entrepreneurs and ended with an evaluation that familiarized students in learning activities of high order thinking skill or HOTS. So that students have good market needs analysis skills and are able to make choices. The emphasis on strengthening the mindset can be seen at the beginning and with the production-based learning model it is clear from the exercises presented.

The results of the validation by marketing expert concluded that the textbook materials developed were good. There are inputs given relating to the inclusion of online marketing materials which are now very developed in the community. Students are introduced to business start-up so that it strengthens students' courage and mindset to get used to real product introduction activities to the market.

The validation results from book design expert have been rated very good for writing letters, it is clear that there is a difference between motivational introduction, titles, subtitles and content, with attractive layouts, font styles, spacing, and empty fields are good. Design expert suggest to differentiate between writing and lettering for a brighter motivational preface so that it is interesting for students to read or open the link provided. It is also recommended to differentiate the color of writing so that students will be interested in reading the textbooks that were developed.

\subsection{Initial Product Improvement}

Based on the inputs given by the three experts, initial improvements were made to the Creative Products and Entrepreneurship Textbook, in the form of adding a chapter related to online marketing materials for the developed textbooks, changing the shape of the letters for motivational introductions and also giving different colors and making corrections for writing errors. 
To strengthen the corrections and validations carried out by experts, the resulting textbook draft was given to 3 Tourism Vocational School students to assess readability, appearance, presentation of material and benefits. 3 students who are asked to attend school are expected to have different abilities so that student representation can be representative for those with average, below average and above average abilities. As for the results obtained in outline as follows:

a. For readability, the score is 3.5 with a very good category. This means that the developed textbooks can be read and understood clearly. The location of punctuation marks, capital letters and lowercase letters is clearly visible. Beheading sentences properly so as not to damage the meaning of the sentence.

b. For the display obtained an average value of 3.1 with a good category. Which means that the appearance of the developed textbook is already attractive to students. There is a clear distinction between sections, there are interesting color variations, it looks different between the content of the material and the motivational introduction where the color for the motivational introduction is chosen brighter.

c. For the aspect of presentation of the material obtained a value of 3.2 with a good category. Which means that the material contained in the PKK textbooks that have been developed is coherent, according to the specifications and syllabus and helps students understand the learning material in series and gradually.

d. For the Benefit aspect, the score is 3.52 with a very good category. Which means that students assess the PKK textbooks that have been developed to provide great benefits for them and strengthen students' mindsets to dare to become entrepreneurs.

Students' assessments for the four aspects evaluated can be said to be good, all of which are above the number 3 which means good even for readability and usefulness reaching 3.5 which is very good. In the results of this test, students suggested that it be equipped with explanations for words that come from foreign terms and which are not used to hearing in everyday language, and there are still some typing errors.

Based on input from students in the one by one test, improvements were made by giving explanations for foreign terms and replacing terms that are still rarely heard with more ordinary words in everyday life that are in accordance with Indonesian language rules and are familiar in the learning environment. As well as repairs are also made for word writing errors that are still found.

\section{Conclusion}

The Textbooks of Creative Products and Production-Based Entrepreneurship with the strengthening of a developed mindset can attract students to become entrepreneurs in the tourism business sector. Textbooks of Creative Products and Production-Based Entrepreneurship with a strengthened mindset developed can be easily understood in learning activities both in class and independently. The exercises presented at the end of each chapter can be used to facilitate students learning to analyze needs in the tourism business and familiarize students with making choices. This strengthens learning activities that are always directed at high order thinking skill (HOTS). Textbooks of Creative Products and Production- 
Based Entrepreneurship with the strengthening of the developed mindset can build students' mindsets to dare to become young entrepreneurs by providing motivation to build a mindset and presenting potential resources and market potential in the tourism industry.

To make it easier for Tourism Vocational High School students to master all competencies in Creative Products and Entrepreneurship subjects, it is recommended for schools to continue mentoring activities to produce products that have been initiated by students so that their entrepreneurial competencies can still be developed in a professional direction. In order to maximize the use of production-based Creative Products and Entrepreneurship textbooks by strengthening the mindset that has been developed, subject teachers should be able to understand the basic concepts of production-based learning models and their syntax and always provide motivation and space for students to dare to try.

\section{Reference}

[1] Kurniawan A, YunYun. Pengaruh Kompetensi Kewirausahaan dan Kelanggengan Usaha Terhadap Keunggulan Bersaing. Jurnal Inspirasi Bisnis dan Manajemen. 2018; 2(1):65-78.

[2] Agung DA. Model Pembelajaran Untuk Mengenalkan Kewirausahaan Pada Siswa Sekolah Dasar. Jurnal Bangun Rekaprima; 2017; 3.

[3] Ayu D. Pengembangan Metode Pembelajaran Kewirausahaan Berbasis proyek untuk Meningkatkan Karakter wirausaha Mahasiswa di Politeknik Negeri Medan. Jurnal Akuntansi dan Manajemen. 2016; 23(1): 16-28

[4] Gunawan, Ignasius B, Adikampara IM. Kesempatan Kerja Bagi Masyarakat Dengan Adanya Bali Safari dan Taman Laut di Desa Serongga Kabupaten Gianyar. Jurnal Destinasi Pariwisata. 2018; $6(2)$.

[5] Nita DL. Analisis Penerapan Kurikulum 2013 Dalam Meningkatkan Kualitas Pembelajaran Ekonomi di SMK Negeri Se Kota Padang. Jurnal Neraca. 2018; 2(1): 68-79.

[6] Disman HN, Dadang D. The Effect of Implementation Collaborative Learning Model of Group Investigation Techniques On Analitica Thinking Skills of Students. Jurnal Manajerial. 2018; 3 (5): 157

[7] Nuri, Rosilawati A. Pembelajaran Berbasis Produksi Sebagai Upaya Peningkatan Keterampilan Produktivitas Siswa SMK. Jurnal Physics Communication. 2018; 2(1):46-51

[8] Lilis M, Rusdarti. Model Pembelajaran Production Based Learning Training Pada Pembelajaran Prakarya dan Kewirausahaan. Economic Education Analysis Journal. 2018; 7(3).

[9] Prabawa, Putra DGA, Pengembangan Bahan Ajar Multimedia Berbasis Proyek Untuk Meningkatkan Hasil Belajar Siswa SMK, Jurnal Pendidikan dan Pegajaran jilid 46. 2013; 3: 206217. 